\title{
Evaluation of No Smoking Area Policies in Makassar City
}

\author{
Rini Anggraeni ${ }^{1}$, Novi Angraini ${ }^{2}$, Erva Novitasari $^{3}$ \\ \{rinianggraeni@unhas.ac.id ${ }^{1}$, ervanovitasari@gmail.com ${ }^{2}$, novinovi.nagmail.com ${ }^{2}$ \} \\ Faculty of Public Health Hospital Management Universitas Hasanuddin ${ }^{1}$ \\ Public Health Hospital Management Universitas Hasanuddin ${ }^{2,3}$
}

\begin{abstract}
Control of cigarette smoke in public places is a solution to maintain health that is possible by arranging regulations for no-smoking areas. The aim of the study was to determine the implementation of Makassar City Regional Regulation No.4/2013 focusing on non-smoking areas in Makassar City hospitals. The method of the research was qualitative with phenomenological design. This research was conducted in two hospitals, were RSI Faisal and RSUD Kota Makassar with the total of nine informants for each hospital selected through snowball sampling technique. Data collection was in the form of in-depth interviews and observations, and data analysis used content analysis. The results at RSI Faisal showed that the implementation of Makassar City Regional Regulation was not optimal, yet due to less commitment of the involved actors, no flow of coordination in the regional regulations and lacking in discipline of the hospital supervision. The research discovered that there was no maximum socialization and communication from the government on no smoking areas regulations in Makassar. The informants did not know the contents of the regional regulations, but they understand the rules of no smoking area and the implementation in the hospital. Conclusion, policymakers should apply socialization of Makassar City Regional Regulation No. 4 of 2013 on no smoking area. All implementers have to committed, and coordinate based on the explanation in the regional regulations. The supervision also must be strict and set sanctions who violate.
\end{abstract}

Keywords: Policy, Tobacco, hospital.

\section{Introduction}

Smoking has now become a lifestyle for most people in various circles. Cigarettes that are sold freely on the market are one of the products with a relatively high level of consumption in the community. Nearly 6 million people die each year from cigarette consumption and exposure to cigarette smoke and account for $10 \%$ of all deaths [1].

According to the WHO report on world cigarette consumption, smoking prevalence rates in Indonesia are among the highest in the world, with $71.8 \%$ of men and $4 \%$ of women aged $\geq 15$ years classified as smokers (WHO, 2015). The average number of cigarettes consumed by people in South Sulawesi per day is 14.6 cigarettes [2]. One of the efforts to overcome the health problems caused by cigarette smoke or the wrong smoking behavior is needed by community empowerment activities or programs that can protect passive smoking. The activity is to form an area that is free of cigarette smoke [3] In reality smoking rooms or smoking areas with air ventilation have been scientifically proven to be ineffective in protecting passive smokers from the carcinogenic effects caused by people smoking in the 
same room because even the most modern ventilation technology cannot eliminate harmful toxins contained in cigarette smoke other people). The dangers of smoking have become a special concern in Indonesia as evidenced by the issuance of regulations on cigarettes, for example the provision of areas without cigarettes, restrictions on cigarette sales, restrictions on the promotion and advertising of cigarettes, restrictions on nicotine and tar content in cigarettes with the intention of providing health protection to the public against the dangers of smoking [4].

There are several studies on the application of Makassar City Regulation number 4 of 2013 concerning non-smoking areas. One of them stated that after the implementation of the policy at Stella Maris Hospital and Haji Hospital some positive changes were felt by both employees and the community in the hospital and benefited the community (visitors) both in terms of social, environmental and health [5]

In addition to Makassar City, other regions have regulations that regulate KTR in their respective regions and have different impacts. In Medan City in a study conducted that informants were aware of the application of KTR in Dr. Pirngadi Medan, however, appeals about KTR to hospital staff were still low so that smokers were still found on the page of the RSUD (6) In Manado City the application of KTR in Level III Hospital R.W. Mongisidi Manado is not yet one of the causes because supervisors lack discipline in recording violations and applying sanctions according to existing regulations. This happens because policy implementers have different characteristics so that in applying KTR special attention is needed by the place applied [6]

One area that is stated to be prohibited from smoking, producing, selling, advertising, and promoting cigarettes is a hospital area. The function of the hospital is to treat sick people. Aside from being a health service place, the hospital is also a public place that anyone can visit. Not only sick people, visitors, but even sellers can also enter it. No doubt, with a large number of visitors coming, there are still people who casually smoke in the hospital area even though there are already warning signs forbidden to smoke, hospitals have an obligation to enforce the entire hospital environment as a non-smoking area, which aims to protect people's health people who are in the hospital environment (passive smokers) from the adverse effects of smoking habits and disruption of cigarette smoke and to create a clean, healthy and free of cigarette smoke [7].

The emergence of a Policy on Non-Smoking Areas (KTR) shows the government's efforts to tackle smoking-related problems. Especially in Makassar City, there is a Makassar City Regional Regulation no. 4 of 2013. Based on these rules, one of the places declared as a Non-Smoking Area (KTR) is a Health Service Facility. One of them is the Faisal Islamic Hospital of Makassar City.

Based on this, the researcher will conduct a study to study the description of the implementation of the No Smoking Area Policy (KTR) in Makassar City. The theme of the problem formulation is how is the description of the implementation of the No Smoking Area Policy (KTR) at the Faisal Islamic Hospital and Makassar City Hospital in 2018?.

\section{Method}

The method used qualitative research with the phenomenological design. In this study, informants were selected using snowball sampling technique. Snowball sampling is a data source sampling technique that at first, a small amount has not been able to provide complete 
data, it must find someone else who can be used as a data source and obtained nine informants for each hospital. Data collection in the form of in-depth interviews and observations.

Data collection methods used in this study are in-depth interviews, by conducting a question and answer with informants and observations or observations. Data analysis uses content analysis. This research was conducted in two hospitals, namely RSI Faisal and RSUD Kota Makassar. The researchers conducted in-depth interviews with 9 informants and 2 Hospital visitors.

Researchers use triangulation to guarantee and reflect the accuracy of the information collected. In qualitative research, the number of informants is usually small. Therefore the validity used in qualitative research is called triangulation which includes source triangulation, method triangulation, researcher triangulation, theory triangulation, and situation triangulation

\section{Results}

This study discusses the evaluation of the implementation of Makassar city regional regulation No.4 of 2013 concerning Non-Smoking Areas in Makassar City Hospital. In this study, data collection was carried out by the researcher as the main instrument through in-depth interviews using interview guidelines that had been prepared in advance and supplemented by observation as a method to support the results of this study conducted during the data collection process.

\subsection{Implementation of public policy to evaluate the implementation of no smoking area at Faisal Islamic Hospital in Makassar City}

Implementation of Makassar City Regional Regulation No. 4 of 2013 concerning no smoking area at Faisal Makassar Islamic Hospital is not maximal. There are 2 factors that must be considered in policy implementation, to wit the contents of the policy and policy environment. Having researched in the field can be seen in terms of the policy environment were:

\subsubsection{The Environmental Policy}

Power, interests, and strategies of the actors involved

The power, interests, and strategies of the actors can expedite the running of KTR regulations. The following is the role of the institutions involved in the KTR regulation. The results of in-depth interviews conducted by informants, mostly informants, answered that there was no flow of coordination between policy makers (the government) and policy implementers (hospitals) and policymakers only merely conveyed circular letters related to the regulations.

\section{Characteristics of Institutions}

The characteristics of an institution are the quality, characteristics, or distinctive features of the institution. In this variable can be seen how the characteristics of the institution in the implementation of KTR regulations. This study obtained information about the characteristics of government and hospital institutions. The government has never carried out supervision and 
imposed sanctions in accordance with the regulations set by the regional government and there are no sanctions set by the hospital, just a reprimand.

\section{Compliance and Responsiveness}

Compliance and responsiveness are how the behavior and attitudes of informants towards the implementation of KTR Regional Regulation. This can be seen from the support in implementation and sensitivity in implementing the regulation. Conclusions in terms of supporting policy implementers in the implementation of local regulations, showed all informants supporting the implementation of KTR regulations at the hospital.

\subsubsection{The Policy Content}

\section{Affecting interests}

The intended interest is an interest group that is able to influence the implementation of the policy, in this case, the KTR regulation. Based on the results of interviews all parties have an interest in having influence because, between the governments, the hospital or the visitors each have their own authority and duties.

\section{Benefit Type}

The type of benefits generated in implementing the KTR regulation is the need for policy implementers. A statement from the interview of respondents that the hospital carries out promote and preventive efforts in controlling cigarettes and for the hospital community the benefits obtained are protected from the dangers of smoking.

\section{Degree of Change}

The degree of change is the target of the changes achieved from the implementation of KTR Regional Regulation in hospitals. Based on the results of the interview, it was concluded that the informant revealed the changes that were felt before and after being determined by the non-smoking area in the hospital, namely the many appeals/posters scattered in the hospital environment and the decline in the number of smokers in the hospital.

\section{Decision-Making Location}

What is meant by decision making here is how important the role and position held by policy makers in decision making can influence the implementation of KTR regulations. There is no SK / PJ made in Faisal Islamic Hospital as the KTR supervisor, the supervision is handed over to the security guard because the security guards most often meet the hospital environment. Decision making is returned to those who have the obligation to implement the KTR, the head of the hospital

\section{Program Implementation}

The results of the implementation of a good program are one of the evidence of an implementer running KTR Regional Regulation. From the answers from the statements 
submitted to the informants, all informants said that the infrastructure/media installed in the hospital did not see the provisions of the regional regulations. Faisal Islamic Hospital has posters and appeals about non-smoking areas scattered in hospitals. But the guidance and supervision of the mayor and the head of the related service were never carried out at Faisal Islamic Hospital.

\subsection{Implementation of public policy to evaluate the implementation of no smoking area In Kota Makassar Regional Public Hospital}

The results of this study were to evaluate the Implementation of Non-Smoking Areas at the Makassar City Regional Hospital. In this study, there are 4 factors that must be considered in the implementation of policies, namely Communication, Attitude, Resources, and Bureaucratic Structure.

\section{a) Communication}

This section discusses the form of socialization carried out by the Makassar city government against the Makassar city regulation No.4 of 2013 in the Makassar City Hospital, the source of information that influences informants' knowledge of the existence of Makassar city regulations No.4 of 2013 concerning Non-Smoking Areas, and the appeal of the Makassar city government for the implementation of regional regulations on Non-Smoking Areas in Makassar City Hospital.

\section{1) A form of socialization of Makassar City Government in Kota Makassar}

\section{Hospital}

Based on in-depth interviews carried out to most informants said that there was no direct information or socialization from the Makassar City Government regarding the existence of the Makassar City regulation. There were also informants who were skeptical about whether the Makassar City Government had conducted socialization in Makassar City Hospital or not.

2) Sources of information obtained by informants to find out about the PERDA of Makassar City No.4 of 2013 concerning KTR.

Based on in-depth interviews, all informants had heard and read about information about the existence of KTR regulations in the city of Makassar through media such as newspapers, TV, and information from friends to friends, but had never read the contents of the local regulations. Communication carried out by the Makassar City Government on the application of the implementation of the Makassar No.4 PERDA implementation of KTR in Makassar City Hospital. The result from in-depth interviews conducted with informants, most of them stated that there had been no direct or official calls made by the Makassar city government for the implementation of regional regulations on non-smoking areas.

However, there is an opinion from one of the informants that the Makassar city government has not directly called for it through newspapers and circulars. From the answers above which consist of several questions to obtain information from informants related to the communication that was established between the local 
government and the Hospital, the communication between the Makassar city government and the hospital during the publication of regional regulations on NonSmoking Areas did not go well according to the informants who claimed to have never directly communicated and the absence of direct mail.

\section{b) Resources}

1) The readiness of Human Resources (HR) owned by hospitals

Based on in-depth interviews, most of the informants revealed that the available HR at this time is sufficient, enough to involve existing employees or HR to supervise the matter. But two informants wanted special human resources to handle the application of no-smoking areas. Some informants said that the need for special oversight teams to monitor KTR in hospitals.

2) Other Resource Readiness

Most of the informants considered that there were enough human resources in the hospital, such as an existing speech board, KTR appeals stickers also existed in every room. But there was also information that said that they still needed some other additional human resources such as multiplying speech boards, and the addition of CCTV to maximize the implementation of no-smoking areas in hospitals. But there were also informants who proposed to have a special room for smokers.

3) Cost assistance from the Makassar city government for the implementation of Non-Smoking Areas in Makassar City Hospital.

The results of in-depth interviews conducted by informants said that they never received financial assistance or funds from the government, and most of them used hospital operational funds that were included in the communication budget for implementing Non-Smoking Areas in Makassar City Hospital. Regarding the availability of resources currently owned by both human resources and other resources. Most of the informants said that there was no need for additional human resources to supervise the implementation of the No-Smoking Area, simply assigning some existing employees. While there were also informants, who said that there was still a need for additional human resources to be tasked with overseeing the implementation of the Non-Smoking Area. Regarding the readiness of other resources, most informants said that infrastructure resources are currently lacking, for example, there is still need for additional CCTV, a smoking ban, and banners that need to be considered. Through the testimony of the elemental informants said that so far there has been no direct assistance from the Makassar city government in the form of funds or infrastructure (smoking ban).

\section{c) Attitude}

1) The attitude of the informant to the existence of the Makassar city area no. 4 of 2013 concerning the non-smoking area (KTR).

A statement regarding the attitude of informants regarding the existence of the Makassar city regulation No.4 of 2013 concerning KTR, all informants said that the presence of the KTR regional regulation was very good because it was able to control smokers not to smoke in a 
non-smoking environment. While the informants who think that we just start from the awareness first, without any rules if the community is aware of the fact that no one else is smoking.

\section{2) The attitude of the informant to support the implementation of Non-Smoking Areas in Hospitals}

The attitude of the informant to the support of the implementation of the no-smoking area in the hospital illustrates that all informants strongly support the implementation of KTR in the hospital. The government has made rules regarding the ban on smoking in hospitals and hospitals are public spaces so that all informants behave to support these rules.

\section{3) The attitude of the informant to the existence of advertising and selling cigarettes in the hospital environment.}

Most of the informants revealed that there should be no advertisement, let alone selling cigarettes in the hospital environment because it has become a hospital rule that applies KTR. But there are also informants who believe that it doesn't matter if the canteen sells cigarettes because they return from the behavior of someone who wants to smoke or not in the hospital environment. From the answers above which consist of several questions regarding the attitude of the informant to the existence of Makassar city regulations No. 4 of 2013 on NonSmoking Areas in Makassar City Hospital, all informants said that the presence of KTR regulations was very good because it was able to control smokers not to smoke in a nonsmoking environment. The attitude of the informant to the support of the implementation of the no-smoking area in the hospital, all informants strongly supported the implementation of hospital work, and the attitudes of informants regarding cigarette advertising and sales most of the informants revealed that there should be no advertisements, let alone selling cigarettes in the hospital environment. It became a rule of hospitals that implemented the KTR, but there were also informants who allowed it.

\section{d) Bureaucratic Structure}

The ideal form of bureaucratic structure to support the effectiveness of the implementation of Non-Smoking Areas in Makassar City Hospital.

Regarding the bureaucratic structure of the results of in-depth interviews, all informants from community service circles said that there was no need for a special bureaucratic structure, just assign some employees whether security guards, others said that it was better to monitor each other. And there were also informants who said that it was more effective to establish a task force team for non-smoking areas. 


\section{Discussion}

The non-smoking area is a room or area with the outer fence boundary which is declared prohibited for smoking activities or activities of producing, selling, advertising, and promoting tobacco. Makassar City Regional Regulation No. 4 of 2013 concerning Non-Smoking Areas is a government effort to protect non-smokers from exposure to cigarette smoke. The regulation has objectives that are in line with hospitals that are healthcare facilities.

The hospital is a health service facility that carries out health efforts namely every activity to maintain and improve health and aims to realize optimal health status for the community [8]. One of the health efforts carried out by the hospital is to protect and guarantee the rights of every person in the hospital environment to breathe clean air without exposure to cigarette smoke. The form of the effort that was carried out was applying the No Smoking Area (KTR) based on the Makassar City Regional Regulation No. 4 of 2013.

Policies regarding non-smoking areas aim to reduce the growth of smokers and people exposed to cigarette smoke in Indonesia. As we know that cigarettes are one of the risk factors for various diseases, one of them is cancer, heart and other non-communicable diseases, which currently shows the biggest contribution to morbidity and mortality in Indonesia. With No Smoking Area, it is expected to be able to change people's behavior to live healthy, improve optimal work productivity, realize healthy and clean air quality free from cigarette smoke, reduce the number of smokers and prevent novice smokers and create a healthy young generation.

The first requirement for effective policy implementation is that those who implement the decision must know what they have to do. Every decision from the policy must be forwarded to the personnel who will carry out the policy. According to [9], if the implementation of the policy wants to be effective, then the implementation order must be consistent and clear. Based on the results of this study related to the communication that exists between the Makassar city government and the hospital in the implementation of the Makassar city regulation No. 4 of 2013 concerning Non-Smoking Areas in Makassar City Hospital shows that it is not going well. This was evidenced by the results of in-depth interviews conducted with informants which resulted in the majority of informants saying that they had never received socialization directly from the city government of Makassar regarding the regulation of the No Smoking Area.

The informant also revealed that so far there had been no call from the Makassar city government in the form of an official letter for the implementation of the regional regulation on Non-Smoking Areas of Makassar City Hospital. In policy, it is necessary to take into account the strength or power, interests, and strategies used by the actors involved to facilitate the implementation of a policy. Based on the KTR Regional Regulation, the power of the highest implementer involved in this organization was the Mayor of Makassar. Next to the technical power in the field is the head of the hospital. Power and authority in organizing socialization activities remain with the Mayor of Makassar because in this case, the head of the hospital is only as of the implementing implementer in the field only in the sense of not having the power or authority to decide policies in policy implementation.

Based on the results of this study related to the communication that exists between the Makassar city government and the hospital in the implementation of the Makassar city regulation No. 4 of 2013 concerning Non-Smoking Areas in Makassar City Hospital shows that it is not going well. This was evidenced by the results of in-depth interviews conducted with informants which resulted in the majority of informants saying that they had never received socialization directly from the Makassar City government regarding the regulation of 
the No Smoking Area. The informant also revealed that so far there has been no call from the Makassar City government in the form of an official letter for the implementation of the regional regulation on Non-Smoking Areas of Makassar City Hospital. In policy, it is necessary to take into account the strength or power, interests, and strategies used by the actors involved to facilitate the implementation of a policy. Based on the KTR Regional Regulation, the power of the highest implementer involved in this organization was the Mayor of Makassar. Next to the technical power in the field is the head of the hospital. Power and authority in organizing socialization activities remain with the Mayor of Makassar because in this case, the head of the hospital is only as of the implementing implementer in the field only in the sense of not having the power or authority to decide policies in policy implementation.

Based on the results of the study, it can be concluded that there is still a lack of communication and socialization carried out by the Makassar city government related to the regulation of No Smoking Areas in Hospitals that are obliged to implement it as stated in the Makassar city regulation No. 4 of 2013, namely healthcare facilities, teaching and learning processes, playgrounds, places of worship, sports facilities, public transportation, workplaces and public places. The Hospital is one part of the facility that is obliged to apply the No Smoking Area by the provisions in the No Smoking Area regulation. Socialization can be done in two ways, namely, verbal by providing information to the public or leaders of each institution directly by conducting socialization and nonverbal namely, by using media such as newspapers, bulletin boards, social media and so on.

Resources have a very large influence on the success of policy implementation. Because with the availability of sufficient resources, it will facilitate the purpose of a policy is achieved. The resources in question are human resources and non-human resources. Human Resources is the most important thing in the effectiveness of implementing a policy. Many programs that fail to be implemented due to lack of human resources or lack of skills and knowledge of human resources so that the implementation of a policy is not running optimally. As happened in the Makassar City Hall and the Makassar DPRD office. Based on the results of research from [8] revealed that as many as 169 respondents (69.3\%) of smoking employees in the No-Smoking Area had been implemented and only 75 respondents or about $30.7 \%$ were smoking outside of the Non-Smoking Area. This shows that there is a lack of supervision in the office so that there are still many people who do not comply with the NoSmoking Area regulation. Lack of supervision means that it is related to the lack of human resources owned to maintain the implementation of the Non-Smoking Area [8].

The results of this study conducted through in-depth interviews with informants, regarding the readiness of human resources owned by hospitals, the most informants said that the human resources currently owned are ready, do not require additional human resources, enough to assign several employees to be a supervisor in making effective implementation of NonSmoking Areas in hospitals.

In addition to human resources, which is no less important is the availability of non-human resources such as supporting facilities, rules, and so on. The implementation of a policy is not able to run optimally if it is not supported by facilities or other resources that support the effectiveness of the implementation of the policy.

From interviews conducted with informants regarding the availability of non-human resources in hospitals for the effective implementation of Non-Smoking Areas, most informants revealed that they still needed additions such as, CCTV and additional banners for the implementation of Non-Smoking Areas and there were some informants who proposed to provide special rooms or a special area for smokers in the hospital even though this is contrary to the Makassar city regulation No. 4 of 2013 which does not allow this. Based on KTR 
regional regulation article 16 the head of the hospital is obliged to make and install smoking bans/instructions/warnings. The head of the hospital or the person in charge has the obligation to give warning and warning to In the implementation of the KTR policy, the characteristics of the institutions involved are the Mayor of Makassar, the Head of the relevant Office, the Hospital Leader, who determines that this KTR policy can be implemented or vice versa. The Mayor, as the policy maker and policy implementer, has never coordinated with the hospital in terms of implementing this policy.

The Mayor has never carried out socialization, supervision, and implemented direct local regulations. Whereas based on article 19, the mayor has the authority to conduct guidance and supervision on non-smoking areas in the form of task forces for non-smoking regional enforcement. This authority can be delegated to the head of the service. The mayor is obliged to give awards to those who have the best wishes to help enforce KTR regulations, including the task force that has been formed. The implementers are kind and caring, in the sense of supporting a policy, they likely carry out policies as desired by the original decision makers. In contrast, if the implementers' attitudes or perspectives are different from those of decision makers, the process of implementing a policy is increasingly difficult.

The results of in-depth interviews conducted by researchers to informants to find out the attitude of informants to the existence of regional regulations without smoking, all informants expressed an attitude of supporting the existence of local regulations in hospitals. In addition, the researchers also explored the responses of informants regarding the attitude of informants on cigarette advertising and sales. Most of the informants revealed that it was appropriate that there should not be advertisements let alone the sale of cigarettes in the hospital environment because it had become a rule of hospitals that implemented the KTR, but there were also informants who make it happen.

Although implementers feel they already know what and how to do it, have the desire to run it and have sufficient resources, implementation still fails if the existing bureaucratic structure hinders the coordination needed to implement the policy

Based on the results of interviews conducted, informants revealed that they did not have a bureaucratic structure in the application of no-smoking areas in Makassar City Hospital, the informants also argued that there was no need for a special bureaucracy to be made, just assign some employees whether security guards, some said that we just watching each other. And there were also informants who said that it was more effective to establish a team of staff for non-smoking areas in hospitals.

\section{Conclusion}

Implementation of the Makassar city area No. 4 of 2013 concerning Non-Smoking Areas in Makassar City hospitals did not go well because there was no official letter addressed directly to the hospital. There is no flow of coordination between policy makers and policy implementers so that the authority determined in the regional regulation does not work and the role of each actor is not implemented properly.

Resource factors in the implementation of Makassar city regulations No. 4 of 2013 concerning Non-Smoking Areas in Makassar City Hospital, the informant revealed that the human resources currently owned are sufficient, and for other resources still need additions such as CCTV, Banners on Smoking Prohibitions or speech boards and special spaces or areas for the smoker. Resources in this case informants support the KTR policy, but the supervision carried out by security guards is not optimal so that there is still escaping supervision. The 
infrastructure/media owned by the Faisal Islamic hospital appears to be visible from the outer fence of the hospital but not in accordance with the existing regulations. In the implementation of regional regulation No. 4 of 2013 concerning Non-Smoking Areas in Makassar City Hospital, informants agreed and supported the existence of Non-Smoking Areas in Makassar City Hospital by not smoking in the Hospital area.

Policymakers should conduct a socialization of Makassar City Regional Regulation No. 4 of 2013 concerning a no-smoking area so that policy implementers fully understand what they apply. All implementers are committed and coordinate according to what has been explained in the regional regulations. Also, the supervision carried out must be firm and apply the sanctions set out in the regulations. For the city government of Makassar to maximize communication with the hospital related to the implementation of local regulations on KTR and a special task force/team was formed to supervise Non-Smoking Cultivation to be more effective in KTR supervision

\section{References}

[1] World Health Organisation(WHO):: Global Health Risks. WHO Libr Cat Data Glob.Vol.1, pp 62 (2009)

[2] Badan Penelitian dan Pengembangan Kesehatan.: Riset Kesehatan Dasar (RISKESDAS) 2013. Badan Penelit Dan Pengemb Kesehat Kementeri Kesehat Ri Tahun 2013. pp.1-384. (2013)

[3] Moore K, Borland R, Cummings KM, Fong GT.: NIH Public Access.Vol. 57.pp.777-86 (2013)

[4] Budi Rahayu RN. Pengaruh Metode 5As Terhadap Sikap Merokok. pp. 56-117 (2010)

[5] Habibi H, Surahmawati S, Sompo H. Gambaran Implementasi Peraturan Daerah Tentang Kawasan Tanpa Rokok (KTR) Pada RSUD Haji dan Rumah Sakit Stella Maris di Kota Makassar Tahun 2015. Al-Sihah Public Heal Sci J. Vol.8, pp.161-70 (2016)

[6] Muliku HR.: Tingkat Iii Robert Wolter Mongisidi Manado Masalah merokok saat ini telah menjadi masalah serius berbagai negara di dunia, karena sangat berbahaya bagi kesehatan. Selain itu ada juga masalah kebiasaan merokok di tempat umum, masalah kebiasaan ini akan. Progr Pasca Sarj Univ Sam Ratulangi.Vol.3.pp. 13-29. (2015)

[7] Thakur R, natale A.: UU RI No 44 Tahun 2009 tentang Rumah Sakit. Cardiol Clin. Vol.1, pp. 15 (2009)

[8] Fitriani Sukardi1, Ida Leida M. Thaha1 ID.: Employees Compliance with No Smoking Area in City Hall Council and DPRD Office of Makassar City Departemen Epidemiologi Fakultas Kesehatan Masyarakat Universitas Hasanuddin. pp 4. (2013)

[9] Solicha RA. : Tingkat Pengetahuan Dan Sikap Pengunjung Di Lingkungan Rsup Dr. Kariadi Tentang Kawasan Tanpa Rokok. (2012) 